\section{8 \\ COAL UTILISATION RESEARCH IN GREAT BRITAIN}

$\mathrm{O}^{\mathrm{N}}$ December 12, Mr. R. W. Foot gave the presidential address to the British Coal Utilisation Research Association, his last before the vesting date of the nationalization of the coal industry in Great Britain. This Association worked for eight years under the control of the Mining Association, which had contributed for maintenance during this period more than eight million pounds. The Mining Association had envisaged the development of a permanent institution, more particularly since the possibility of nationalization of the coal industry was recognized. In that event it was hoped that the National Coal Board would agree to take over the activities of the Association. In anticipation, and in order to prevent the slackening which might arise during a period of uncertainty as to the future, the Mining Association continued its financial support without reservation until the vesting day, January 1, 1947. The National Board has accepted the principle mentioned, and on that day stepped into the shoes of the Mining Association so far as the British Coal Utilisation Research Association is concerned, and was able to find the organisation in a state of full activity.

During its existence, most of which had been during a period of war, the Association concentrated on certain major operations of coal utilization. Mr. Foot, referring to the last three years, mentioned in particular the work of Mr. J. S. Hales on domestic coalburning appliances-a subject touching almost every householder-and described it as a 'landmark' in space heating. So far as Great Britain is concerned, there is some justification for the term. In countries where colder conditions are common, people appreciate the advantages of dispersing available heat throughout their dwellings; in Britain, practice has led to the localization of warmth and its insulation from the rest. Efforts to cope with the effects have of necessity tended to be improvisations. The work of the British Coal Utilisation Research Association has shown how, by more rational design of domestic grates, the effective use of coal heat can be increased, and at the same time can be more widely dispersed through a dwelling. Such principles can be applied generally, and already appliances have been designed whereby a single unit fed by smokeless fuel can be made to serve a whole house. This may lead to a radical change in household practice.

On the industrial side, the use of coal in the generation of steam is the largest outlet, and was given pride of place. Priority was given to the socalled 'shell' boilers-the smaller fire-tube units in common use. Although everywhere in use, it was believed that familiarity had led to neglect in some respects; it was thought that carefully conducted research with modern resources would promote improvements in design and increases in efficiency. The work of a section of the Association under Dr. E. G. Ritchie has confirmed these anticipations. The larger water-tube boilers have been developed under more scientific conditions, mainly stimulated by the needs of electrical industry. In modern practice these encounter extremely severe conditions of operation. It has become a major problem to keep such plant in continuous service, owing to the destructive action of acid and other inorganic materials present in the products of combustion. The work of the Association has already made
February 8, 1947 Vol. 159

contributions to improve the 'availability' for service of large steam generators.

Mr. Foot referred to the 'down-jet furnaces', which arose from work done, during the War, on gas producers. It has led to the construction of a furnace, no bigger than a filing cabinet, but capable of producing per hour $200 \mathrm{lb}$. of steam at $200 \mathrm{lb}$. pressure. It is thought that such a furnace may enable solid. fuels to be used to operate gas turbines.

The Association prosecutes a considerable range of more fundamental scientific work under the direction of Dr. D. H. Bangham. For all these branches there is now a staff of three hundred of all grades, under the control of the director, Dr. D. T. A. Townend. To provide for the necessary accommodation of all kinds, the Association is carrying out at Leatherhead a very extensive programme of building and equipment. It is planned to cope effectively with the great problems of coal utilization which the future promises to bring.

H. J. HodsmaN

\section{CHEMOTHERAPY}

$T$ HE Linacre Lecture, 1946, delivered by Sir Alexander Fleming, on "Chemotherapy, Yesterday, Today and Tomorrow" (Cambridge University Press, 1946. 2s.), has now been published. Opening his lecture with the warning that the title chosen was too ambitious and would require a series of lectures, Sir Alexander limited his remarks to chemotherapy of which he has had first-hand knowledge. $\mathrm{He}$ refuses to confine the meaning of the term 'chemotherapy' to the administration of chemical substances by way of the blood; he extends it to include any form of treatment which enables a chemical substance to exert directly an injurious effect upon bacteria. This definition includes antiseptic treatment, two cardinal principles of which are the avoidance of chemical substances which are too toxic to the host or to the tissues, and the effective diffusion of the therapeutic agent into the infected tissues. Discussing the antiseptic methods of Lister and the practice of asepsis which followed them, Sir Alexander demonstrates, by reference to experience gained during the First World War, how important it is that diffusion of the local chemotherapeutic agent into the infected area should occur and, by reference to the mode of action of Dakin's solution, how important is the drainage of the infected lesion by the exudation of fluid from it. Important also is the action of local chemotherapeutic agents upon the phagocytes which attack the bacteria. Sir Alexander's own work on this problem is well known, and he here shows how essential it is to consider the speed of action of the chemical substance on the bacteria and on the phagocytes respectively. If the phagocytes are killed by it before it kills or appreciably inhibits the growth of the bacteria, the tissues are left without one of their main means of defence.

Sir Alexander points out that scientific chemotherapy began with Ehrlich. He then discusses the aniline dyes, and thus comes to the sulphonamide of chrysoidine (prontosil), with which Domagk began the remarkable series of researches by many workers which have produced the sulphonamides now in use. The relative advantages and disadvantages of the sulphonamides are briefly indicated, and thus we come to the year 1940, when penicillin, discovered by Sir Alexander in 1928, four years before the first sulphonamide 
was prepared and seven years before Domagk demonstrated the effective antistreptococcal action of prontosil, became available in sufficient quantity to enable practical therapeutical tests of it to be made. It is now well known how Sir Howard Florey and his collaborators in Oxford and in the United States made penicillin available and demonstrated its remarkable properties. It is, Sir Alexander says, the most powerful chemotherapeutic drug yet produced, for it will inhibit the growth of Staphylococcus even when it is diluted eighty million times. Adding still further to the discoveries of this fertile recent period, Sir Alexander outlines the properties of gramicidin and tyrothricin, obtained by Dubos in 1939 from a soil bacillus, Bacillus brevis, and those of streptomycin, obtained from Streptomyces griseus by Waksman in 1943 .

Finally, Sir Alexander discusses briefly the possible chemotherapeutic developments of the future. This part of his lecture will perhaps disappoint those readers who expect dramatic prophecies; but, if they are disappointed, they have only themselves to blame, for no man could correctly forecast what may develop from the many possibilities opened up by recent work. Sir Alexander ends with a plea for the establishment of a central Institute of Microbiology, in which all the work now being done could be co-ordinated. The Royal Society called for the establishment of such an institute in 1945. If, says Sir Alexander, we had had such an institute in 1928, when he discovered penicillin but lacked the chemical facilities to develop his discovery, we could have had all the benefits of penicillin much earlier. A small fraction of the money spent upon our national medical, veterinary and agricultural services would endow such an institute. It would be difficult to conceive a project more essentially humane or a better long-term investment for the relatively small funds required.

G. LAPAGE

\section{FORTHCOMING EVENTS}

Monday, February 10

SOOTRTY OF INSTRUMENT TECHNOLOGY, NORTH-WEST SECTION (at the College of Technology, Manchester), at 7.15 p.m.-Dr. H. W. Thompson : "Infra-Red Absorption Methods for Gas Analysis".

\section{Tuesday, February II}

SOCIETY OF Chemical INDUSTRY, Plastics GROUP (joint meeting with the FARADAY SOCIETY, at the Royal Society of Tropical Medicine, Manson House, 26 Portland Place, London, W.1), at 2.30 p.m.-Mr. G. Gee: "The Influence of Molecular Structure on the Elasticity and Tensile Strength of Rubber".

INSTITUTION OF POST OFFICE ElROTRICAL ENGINEERs (at the Institution of Electrical Engineers, Savoy Place, Victoria "Embank-
ment, London, W.C.2), at 5 p.m.-Mr. R. M. Chamney: "Development, London, W.C.2), at 5 p.m.-Mr. R. M. Chamney : "Develop-

ZOOLOGIOAL SOCIFTX OF LoNDON (at Regent's Park, London, N.W.8), at 5 p.m. - Scientific Papers.

ROXAL INsTrTuTION (at 21 Albemarle Street, London, W.1), at 5.15 p.m.-Prof. E. K. Rideal, F.R.S., and Dr. P. Johnson: "Colloids". (Subsequent lectures on February 18, 25 and March 4.)

ILLUMTINATING ENGINEERING SOCIETY (at the Royal Society of Arts, John Adam Street, Adelphi, London, W.C.2), at 6 p.m.-Mr. J. S. Smyth: "The Brightness and Legibility at Night of Road Traffic SOCIETT OF PUBLIC ANALYSTS AND OTHER ANALTTICAL CHEMISTS,
PHYSIOAL METHODS GROUP (at the Chemical Society, Burlington House, Piccadilly, London, W.1), at 6 p.m. - Short papers on "Fluorimetric Analysis".

ShEFrikLd Metalturgical Association (joint meeting with the RRFRACTORIES ASSOCIATION OF GREAT BRITAIN and the SHEFFIELD BRANCH of the NATIONAL ASSOCIATION OF CLAYWORKS MANAGERS, at Mappin Hall, Sheffield), at 7 p.m.-Mr. W. T. Hale: "A Statistica Sampling Plan for Refractory Products;"

\section{Wednesday, February 12}

INSTITUTE OF PHYSICS, LONDON BRANCH (at the Royal Institution, Albemarle Street, London, W.1), at 2.15 p.m.-Annual General Meeting. Symposium on "New Optical Materials".
ROYAx SocIety of ARTS (at John Adam Street, Adelphi, London, W.C.2), at 5 p.m.-Dr. F. A. Freeth, F.R.S.: "Economic Reconstruction ; 3, Materials".

Institute of Physics, Manchester and DIstrict BRanch (joint meeting with the SHeFrield PHYsical Sociery, in the Physics Department, The University, Sheffield), at 5.15 p.m.-Dr. C. Sykes, .R.S.: "Physics and Steel Making".

INSTITUTE of PETROLEUM (joint meeting with the ROYAL AERONaUtical Societr, at Manson House, 26 Portland Place, London, W.1), at 5.30 p.m.-Dr. C. G. Williams: "Fuel and Lubricants for Aero Gas Turbines".

Institution of Electrical EngINEers, Transmission SeTion (at Savoy Place, Victoria Embankment, London, W.C.2), at $5.30 \mathrm{p.m}$ -Mr. G. T. Harwood: "The Operational Characteristics of Modern H.V. Wood-Pole Lines;"

Manchester Metalidrgical Societry (at the Engineers' Club, Albert Square, Manchester), at 6.30 p.m.-Dr. L. F. Pfeil: "Metal and Alloys for Service at High Temperatures",

Television SocieTy (joint meeting with the BRITISH Kinemato GRAPH SOCIETY, at Film House, Wardour Street, London, W.1), a 7.15 p.m.-Mr. Marcus F. Cooper: "The Film in relation to Television".

SOCIETY OF DYERS AND Colourists, NORTHERN YRELAND SECTIO (at the Queen's Hotel, Belfast), at 7.30 p.m.-Dr. 'T. Richardson: "The Abbot-Cox Process of Yarn Dyeing as Applied to Cotton".

Sochety FOR VISITING ScIENTISTS (at 5 old Burlington Street, London, W.1), at 7.30 p.m.-Discussion on "The Outlook in Psychology" ('Speakers : Dr. E. B. Strauss, Dr. C. G. L. Pratt and Dr. J. Cohen).

MANCHESTER GeOLOGICAL ASSOCIATION (at the Manchester Geographical Society, 16 St. Mary's Parsonage, Manchester).-Dr. F. M. Coalfleld",

Thursday, February 13

Chemical Society (in the Chemical Department, The University, Woodland Road, Bristol), at 2.15 p.m.-Discussion on "Proteln Chemistry",

SOCIETY OF DAIRY TECHNOLOGY (at the Imperial Hotel, Temple Street, Birmingham), at 2.15 p.m.-Dr. S. K. Kon: "The Effect of Heat-Treatment on

nd Milk Products'.

CHEMICAL SOCIETY (joint meeting with the SHEFFIELD UNIVERSITY CHEMICAL SOCIETY, in the Chemistry Lecture Theatre, The University Sheffield), at 5.30 p.m.-Prof. J. Monteath Robertson, F.R.S.: "Bond Lengths in Aromatic Hydrocarbons".

INSTITUTION OF ELECTRICAL ENGINEERS, INSTALLATIONS SECTION (at Savoy Place, Victoria Embankment, London, W.C.2), at 5.30 p.m. Flectrical Equipment".

Institution of Electronics, N.W. England Section (joint meeting with the MANCHESTER CENTRE of the ILLUMINATINe ENGINEERING SocIETY, in the Reynolds Hall, College of Technology, Manchester), at 6.30 p.m.-Dr. H. Meyers and Mr. G. A. R. Tomes: "Recent Advances in Luminescent Materials for Electronic Devices". WOMEN's ENGINEERING SOCIETY, MANCHESTER BRANCH (at the Engineers' Club, Albert Square, Manchester), at 6.30 p.m.-Members' Night-"Our Jobs and Problems".

Pharmaceutical Societr (at 17 Bloomsbury Square, London, W.C.1), at 7 p.m.-Dr. H. Davis: "Some Chemical and Pharmaceutical Aspects of Anæsthesia",

Royal Photographic Societx (joint meeting of the Screntrifo AND TECHNICAL GROUP and the CoLOUR GROUP), at 7 p.m.-Mr. Percy W. Harris : "Pract
Colour Photography", 4).

SOCIETY OF DYERS AND COLOURISTS, WEST RIDING SECTION (a the Great Northern Victoria Hotel, Bradford), at 7.15 p.m.-Dr. H. P. Staudinger: "Polymer Chemistry".

Chemical Society, Manchester Section (joint meeting with the LOCAL SECTION of the ROYAL INSTITUTE OF CAEMISTRY, in the Chemistry Department, The University, Manchester), at 7.30 p.m.Pharmaceutical Society, Manchester, Salford and District BRANCH (in the Council Chamber, Houldsworth Hall, Manchester) at 7.45 p.m.-Prof. H. Brindle: "Penicillin".

\section{Friday, February 14}

BRITISH Electrical AND ALLIED INDUSTRIES RESEARCH AsSOcIA TION (at the Connaught Rooms, Great Queen Street, London, W.C.2), at 11.30 a.m.-Annual General Meeting.

TeXTile Institute (at 16 St. Mary's Parsonage, Manchester), at 1 p.m.-Mr. P. R. Masheder: "Lubrication-its Application and (

Ori aND Colour Chemists' Association, Manchester Sectior (at the Engineers' Club, Albert Square, Manchester), at 2 p.m.-Mr. D. H. Hewitt: "Further Developments in Styrene Co-Polymers".

Physical Socrety, Optical Grodp (in the Physics Department, Imperial College of Science and Technology, Imperial Institute Road,
London, S.W.7), at 3 p.m. - Mr. L. V. Chilton, Dr. H. H. Hopkins and Mr. J. S. Preston: "Physical Optics and Technical Applications" Dr. W. S. Stiles: "Visual Photometry, Colorimetry and Physiologica Optics" (Reports on the Réunion d'Opticiens, Paris, October 1946). Royar Astronomical Societr (at Burlington House, Piccadilly London, W.1), at 4.30 p.m.-Prof. H. H. Plaskett, F.R.S. : "Astronomical Spectroscopy". Annual General Meeting.

SOCIETY OF Chemical INDUSTRY, Chemical ENGINEERING GROUP (at the Geological Society, Burlington House, Piccadilly, London, W.1), at 5.30 p.m.-Mr. G. Eyssen: "Polyvinyl Chloride and its Co-Polymers". 